FACTA UNIVERSITATIS

Series: Physical Education and Sport, Vol. 16, No 2, 2018, pp. 337 - 346

https://doi.org/10.22190/FUPES180812030P

Research article

\title{
THE STUDY OF THE AGE-RELATED DYNAMICS OF THE REACTION TIME TO VISUAL STIMULI IN SCHOOLCHILDREN
}

\author{
UDC 796.015.54-053.5
}

\author{
Milutin Parlic ${ }^{1}$, Aleksandra Ilić ${ }^{2}$, Vladimir Jakšić², \\ Milan Parlić2 ${ }^{2}$ Vedrana Makević ${ }^{3}$, Sandra Milanović ${ }^{4}$ \\ ${ }^{1}$ Faculty of Sport and Physical Education, University of Niš, Niš, Serbia \\ ${ }^{2}$ Faculty of Medicine, University of Priština, Kosovska Mitrovica, Serbia \\ ${ }^{3}$ Faculty of Medicine, University of Belgrade, Belgrade, Serbia \\ ${ }^{4}$ Faculty of Pedagogy, University of Kragujevac, Kragujevac, Serbia
}

\begin{abstract}
A fast reaction to visual stimuli is important for the success of any athlete. A fast reaction time enables a quick response in key situations. We have studied how age, sport engagement, moderate physical activity and lateralization affect the simple reaction time to visual stimuli in schoolchildren between the ages of 9 and 13. The reaction time to visual stimuli was statistically significantly shorter in older children compared to younger ones. The sport club basketball players who had been training and playing basketball for several years had a statistically significantly shorter reaction time to visual stimuli compared to schoolchildren of the same age from a rural environment who did not engage in sports. Moderate physical activity and lateralization did not significantly affect the reaction time values. The simple reaction time to visual stimuli was used in this study to evaluate the speed and explosive abilities of young basketball players. By training certain movements, we managed to improve their reaction time and thus influence the quality of their game. Integrating training of these skills into sport clubs and schools would affect the improvement of basketball performance and the prevention of injury.
\end{abstract}

Key words: simple reaction time, visual stimuli, physical activity, lateralization

Received September 12, 2018 / Accepted November 6, 2018

Corresponding author: Milutin Parlic

University of Niš, Faculty of Sport and Physical Education, Čarnojevića 10a, 18000 Niš, Serbia

Phone: +381 $18510900 \bullet$ E-mail: parlicm@gmail.com 


\section{INTRODUCTION}

The main features of a basketball game are rapid changes in the direction and the intensity of movement, with or without ball possession (Jakovljević, Karalejić, Pajić, Gardašević, \& Mandić, 2011). The ability to act quickly and the precision of movements in a small space, under the conditions of limited space and time, are characteristic for the actions of basketball players and are directly related to speed and explosive abilities. A high-speed reaction time is necessary in team sports such as basketball where it is desirable to quickly establish a receptor-effector relationship. This ability is predominantly hereditary and very important for basketball players who have to respond quickly to external stimuli (Gavkare, Wanaware, \& Svedi, 2013). Today, great attention is paid to exploring the visual sensory abilities of athletes (reaction time to visual stimuli, visual field width, visual acuity, binocular vision), which are very important elements in improving the game of basketball (Quintana, Román, Calvo, \& Molinuevo, 2007).

Reaction time is how quickly the subject responds to stimuli from the immediate environment. Reaction time measures psychomotor reactivity, a parameter that is considered to be genetically determined. It is measured as a response of the extremities or the entire body to visual, acoustic or other stimuli. Shorter reaction time is a necessary factor for achieving top results, but only in correlation with all other parameters (strength, motion coordination, intelligence, etc.).

Simple reaction time is dependent on age. It improves from early childhood until the late twenties, then gradually slows down until the 50s and 60s, increasing markedly in subjects older than 70 (Luchies et al., 2002; Adam, 1999; Engel, Thorne, \& Quilter, 1972; Bellis, 1933).

Quintana et al. (2007), by examining the visual sensory abilities (visual acuity, binocular vision, horizontal field of vision, simple reaction time and temporal selection of visual stimuli) of schoolchildren aged 11 to13, who played basketball, and comparing their results with the visual sensory abilities of juniors of the Spanish Basketball Federation, found that juniors showed excellent results when testing visual acuity, binocular vision, and the reaction time to visual stimuli in the horizontal field of vision. All of the participants attended a summer camp for 15 days each year, for the last five years. In their research, Davranche, Burle, Audiffren, \& Hasbroucq (2006) also found that active exercise shortened reaction time. In their study, Meden Wright, \& Hamilton (2011) tested the reaction time to visual stimuli of athletes and nonathletes, both male and female, aged 18 to 23 years. The examined group consisted of active athletes, baseball players from the University team, while the control group was represented by students of the same age who did not engage in sports. Athletes trained once a week, and the control group students twice a week for a period of three weeks. The analysis of the obtained results showed that men had a faster reaction time than women and that athletes reacted more quickly to visual stimuli than students who did not engage in sports. Students of both genders who did not actively engage in sports improved their reaction time after three weeks of training. Gavkare et al., 2013, determined the reaction time to audio and visual stimuli of athletes and the control group that consisted of healthy individuals, aged 18 to 25 . It was observed that athletes had a significantly shorter reaction time to both stimuli compared to the control group. The authors consider that the statistically significantly shorter reaction time in athletes was caused by higher concentration, cautiousness, better muscular coordination, and the greater speed and precision of their movements. The authors also emphasize that the reaction time of certain 
movements can be improved by continuous training of these movements. Jain, Bansal, Kumar, \& Singh (2015), conclude in their work that medical students who engage in sports have a faster reaction time to audio and visual stimuli than medical students with a sedentary lifestyle.

Korovljev, Mikalački, \& Čokorilo (2011) tested pre-school children (202 children, 95 of whom were left-handed) and did not determine statistically significant differences in carrying out motor assignments between the right-handed and the left-handed participants. Iteya and Gabbard (1996) claim that right-handed children were better coordinated than the left-handed children. Dane and Erzurumluoglu (2003) observed in their studies that left-handed handball players had a quicker reaction time compared to right-handed ones. When testing the performance of the left hand, the male right-handed handball players had quicker reaction times than the female right-handed handball players. Such genderbased differences were not present when testing left-handed players.

The aim of actual study was to determine the effects of age, sport engagement, moderate physical activity and lateralization on the speed of the reaction time to visual stimuli.

\section{METHODS}

\section{The sample of participants}

The study included a group of 97 participants, male schoolchildren, ages 9 to13. The age of the participants was purposefully selected consulting the literature data, which indicate that schoolchildren between the ages of 8 and 13 go through a sensitive period in which there are optimal conditions for the development of motor skills i.e., maximum speed, higher speed of individual movements, acceleration, explosive power (Trunić \& Mladenović, 2015).

The participants were divided into two groups. The first group of participants consisted of 37 male schoolchildren who played basketball for the Belgrade "Beovuk 72" sports club. The second group of participants acted as a control group, consisting of 60 male schoolchildren, from the "Knez Lazar" Elementary School in Gusterice, Kosovo, who did not actively engage in sports (due to the lack of adequate conditions). All children had the same number of classes in physical education, depending on their age, where children from the "Beovuk 72" sports club trained basketball four times a week for one hour. The children from the "Beovuk 72" sports club did not start training at the same time, so we tested how the length of training affected the speed of their reaction time.

\section{Measuring methods and their organization}

We measured the reaction time to visual stimuli for each participant before and after physical activity. The simple reaction time measurement was carried out using a special program installed on a computer.

Participants sat comfortably facing a $39.6 \mathrm{~cm}$ laptop computer monitor with their dominant arm pronated and resting on a flat surface. They were instructed to press the space bar on the laptop computer keyboard with the hand as soon as they see the visual stimulus in the center of the computer screen (highlighting white circle against a black background). Participants performed 20 test trials. The inter-trial interval varied randomly 
in duration between $1.5 \mathrm{~s}$ and $3 \mathrm{~s}$. After completing the test, average of performances were recorded for each participant (Mišulić et al., 2008).

Simple reaction time test was conducted using special computer program. In order to avoid influence of fatigue the test was always performed at the same time before noon for both the trial and control group (Jakovljević et al., 2008).

The assessment of lateralization was carried out using specialized tests with questions and assignments divided by levels, used for the assessment of the usable and gestural lateralization of the extremities, vision and hearing (Bojanin \& Elim, 1985). In this study, we used a protocol for the examination and evaluation of the dominant usable and gestural lateralization of the extremities, vision and hearing. For example, for the evaluation of the dominant lateralization of the hands, we utilized a test composed of 12 questions, and for the evaluation of the gestural lateralization, we used a test of 6 questions posed by a trained examiner. The examined child was asked to respond by performing a particular action or to specifically demonstrate the task using appropriate props. When testing the dominant usable lateralization of the upper extremities, the examiners asked questions such as: "Show me how you comb your hair." or "Show me how you hold a spoon.", and the like. It was noted which hand the child used to perform the action and based on the collected data it was determined whether the left or right hand were predominantly used by the child, or whether the child was ambidextrous. The similar procedure was used in evaluating the dominant gestural lateralization of the upper extremities. The examined child, when asked "How would you put one fist over the other?", performed the action spontaneously. Based on which hand ended up being the upper hand or, in this case which hand was placed above the other, it was determined which hand was dominantly gestural. After summing up the obtained data, the dominant gestural lateralization was estimated.

Testing and measurings were carried out in the sports hall of the "Beovuk 72" basketball club in Belgrade and the gymnasium of the "Knez Lazar" Elementary School in Gušterica, Kosovo, in accordance with the protocols, in the presence of an optimal number of examiners for each motor skill, with tests used for the assessment of lateralization, and with written consent of the participants' parents obtained prior to testing.

\section{Statistical analysis}

Continuous variables are presented as means \pm standard deviations (SD) and categorical variables were expressed as absolute and relative frequencies. The normality of the data distribution was confirmed by the Kolmogorov-Smirnov tests. Differences between the groups was analyzed using either the independent samples T-test (normal distribution) or the Mann-Whitney test (non-normal distribution). Paired-samples T-test or Wilcoxon rank-sum test was used to estimate the statistical significance difference between the reaction times to visual stimuli pre- and post-training. The correlation of the variables was analyzed by correlation and regression analysis. The criterion for statistical significance was $p<0.05$. Statistical analysis was performed with the Statistical Package for the Social Science Program (version 22, SPSS Inc., Chicago, IL, USA) 


\section{RESULTS}

The pre-training arithmetic mean of the reaction time to visual stimuli among children of the "Beovuk 72" sports club was $297 \pm 35 \mathrm{~ms}$, while the post-training value was $302 \pm$ $37 \mathrm{~ms}$. Using the paired-samples T-test, certain values were obtained $(\mathrm{t}=-0.982, \mathrm{p}=$ 0.333 ) based on which we concluded that there was no statistically significant difference between the reaction times to visual stimuli pre- and post-training. For the schoolchildren from the "Knez Lazar" Elementary School, the mean value of the reaction time to visual stimuli prior to physical education classes was $423 \pm 203 \mathrm{~ms}$, and after the physical education classes it amounted to $379 \pm 85 \mathrm{~ms}$. Using the Wilcoxon's rank-sum test, we obtained certain values $(Z=-1.642, p=0.101)$ based on which we found that the reaction time values to visual stimuli did not show a statistically significant difference before and after the physical education classes (Table 1).

Table 1 The simple reaction time to visual stimuli pre- and post-training in children from the "Beovuk 72" sports club and schoolchildren from the "Knez Lazar" Elementary School, before and after the physical education classes

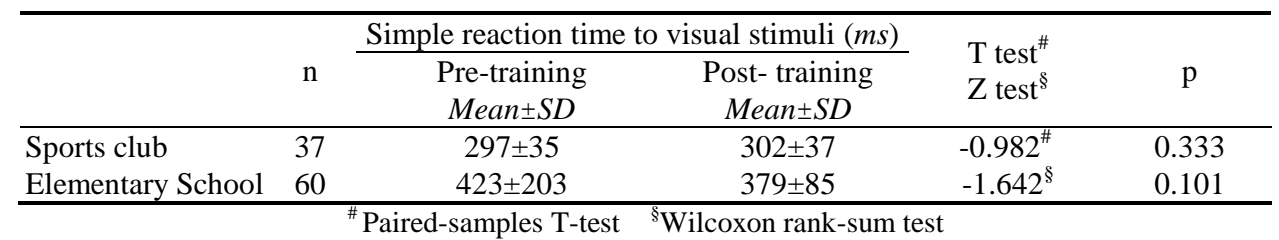

The reaction time to visual stimuli was shorter in children from the sports club who had been training for longer, but the strength of the association indicated no statistical significance $(\mathrm{r}=-0.259, \mathrm{p}=0.121)(\mathrm{Graph} 1)$. The duration of training as an independent variable was not a statistically significant predictor of the reaction time to visual stimuli $(b=-0.701, p=0.121)$.

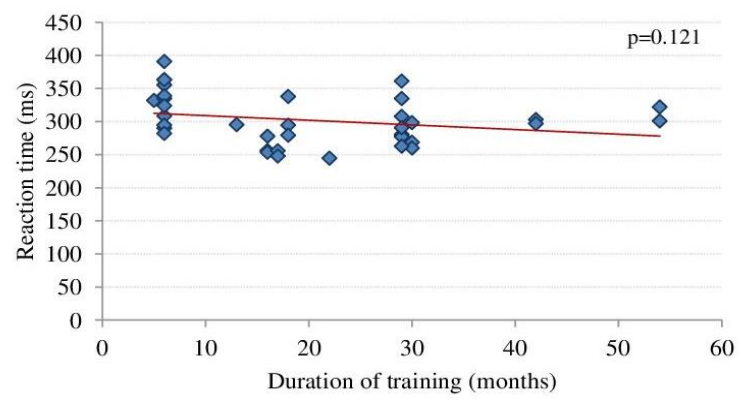

Graph 1 The correlations between the reaction time to visual stimuli and the duration of training in schoolchildren from the "Beovuk 72" sports club

Among the schoolchildren from the "Beovuk 72" sports club, there was a statistically significant negative correlation between the age of the child and the length of the reaction time to visual stimuli $(r=-0.479, p=0.003)$, (Graph 2$)$. The child's age as an independent 
variable was a statistically significant predictor of the reaction time to visual stimuli prior to training $(b=-11.245, p=0.003)$.

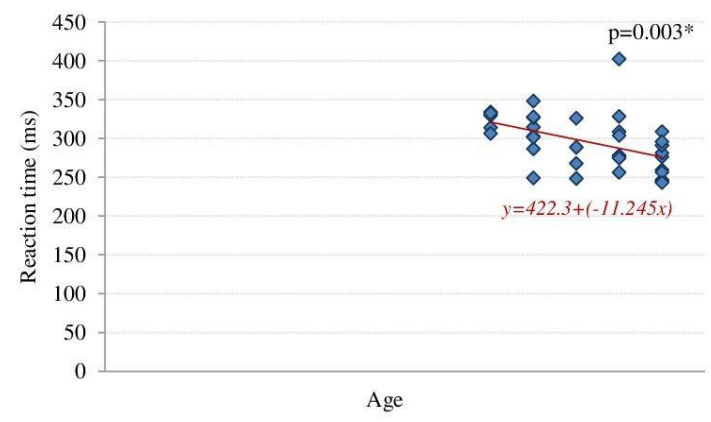

Graph 2 The correlations between the simple reaction time to visual stimuli and the age of schoolchildren from the "Beovuk 72" sports club

Among the schoolchildren from the "Knez Lazar" Elementary School, there was a statistically significant negative correlation between the age of the children and the length of the reaction time to visual stimuli ( $r=-0.461, \mathrm{p}<0.001)$, (Graph 3). The child's age as an independent variable was a statistically significant predictor of the reaction time to visual stimuli $(b=-58.467, p=0.001)$.

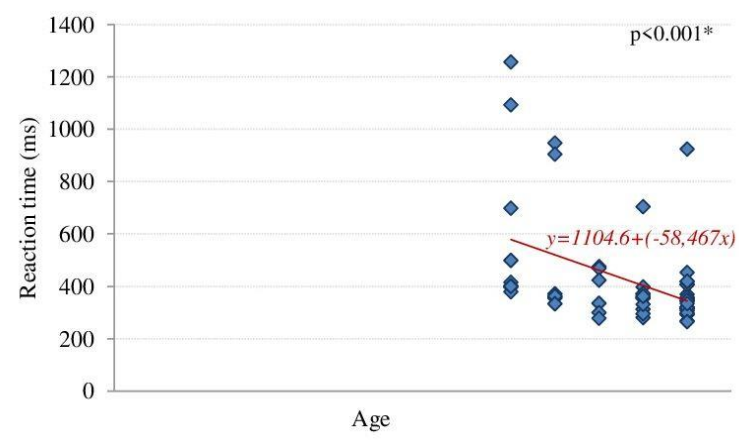

Graph 3 The correlations between the simple reaction time to visual stimuli and the age of schoolchildren from the "Knez Lazar" Elementary School

The mean value of the reaction time to visual stimuli for the right-handed participants was $379 \pm 178$ and for the left-handed participants it amounted to $321 \pm 39 \mathrm{~ms}$. Using the Mann-Whitney test, we obtained certain values $(U=273.0, p=0.558)$ that led us to conclude that the values of the reaction time to visual stimuli did not show a statistically significant difference between the right-handed and left-handed participants. For the schoolchildren from the "Beovuk 72" sports club, the arithmetic mean value of the reaction time to visual stimuli was $295 \pm 36 \mathrm{~ms}$ in the right-handed participants, while it amounted to $303 \pm 29$ $\mathrm{ms}$ for the left-handed participants. Using the independent samples T-test, we obtained certain values $(\mathrm{t}=-0.430, \mathrm{p}=0.670)$ which led $\mathrm{us}$ to conclude that the reaction time to 
visual stimuli did not show a statistically significant difference between the right-handed and the left-handed participants (Table 2).

Table 2 The values of the simple reaction time to visual stimuli among all tested children and only among children from the "Beovuk 72" sports club in relation to lateralization

\begin{tabular}{|c|c|c|c|c|c|c|}
\hline & \multicolumn{4}{|c|}{ Simple reaction time to visual stimuli $(\mathrm{ms})$} & \multirow{3}{*}{$\begin{array}{l}\text { T test } \\
\text { U test }^{\S} \\
\end{array}$} & \multirow[t]{3}{*}{$\mathrm{p}$} \\
\hline & \multicolumn{2}{|c|}{ Right-handed } & \multicolumn{2}{|c|}{ Left-handed } & & \\
\hline & $n$ & Mean $\pm S D$ & $n$ & Mean $\pm S D$ & & \\
\hline$\overline{\text { All tested children }}$ & 90 & $379 \pm 178$ & 7 & $321 \pm 39$ & $273.0^{\S}$ & 0.558 \\
\hline Sports club & 32 & $295 \pm 36$ & 5 & $303 \pm 29$ & $-0.430^{\#}$ & 0.670 \\
\hline
\end{tabular}

Among the left-handed schoolchildren from the "Beovuk 72" sports club, the mean value of the reaction time to visual stimuli was $365 \pm 81 \mathrm{~ms}$, while among the left-handed children from the "Knez Lazar" Elementary School it amounted to $307 \pm 40 \mathrm{~ms}$. Using the Mann-Whitney test, we obtained certain values $(\mathrm{U}=2.0, \mathrm{p}=0.245)$ which led us to the conclusion that the value of the reaction time to visual stimuli did not show a statistically significant difference among the left-handed children from the "Knez Lezar" Elementary School compared to the left-handed children from the "Beovuk 72" sports club (Graph 4).

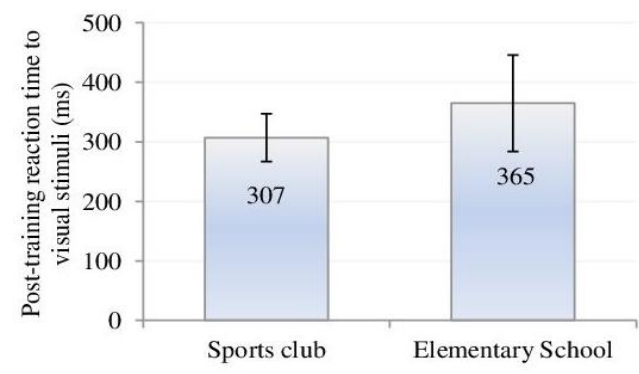

Graph 4 Post-training values of the simple reaction time to visual stimuli in left-handed children from the "Beovuk72" and in left-handed children from the "Knez Lazar" Elementary School

For the children from the "Beovuk 72" sports club, the mean value of the reaction time to visual stimuli was $296 \pm 35 \mathrm{~ms}$ and for the children from the "Knez Lazar" Elementary School was $423 \pm 203 \mathrm{~ms}$. Using the Mann-Whitney test, we obtained certain values $(\mathrm{U}=328.0, \mathrm{p}<0.001)$ that led us to conclude that the reaction time to visual stimuli was statistically significantly longer in the children from the "Knez Lazar" Elementary School compared to the children from the "Beovuk 72" sports club (Graph 5). 


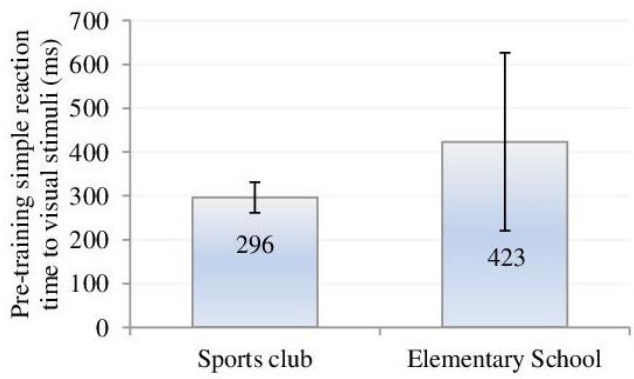

Graph 5 The comparison of the reaction times to visual stimuli between the participants from the "Beovuk 72" sports club and the participants of the control group consisting of the children from the "Knez Lazar" Elementary School

\section{DISCUSSION}

Moderate physical exercise did not have a significant effect on the reduction of the reaction time to visual stimuli in both groups of children, aged 8 to13 (the study group consisted of schoolchildren engaging in sports and the control group of schoolchildren not engaging in sports), which corresponds with some literature data. A number of authors suggested that exercise did not affect the length of the reaction time in the tests performed on football players, but also that exercises on a stationary bicycle did not have an effect on the reaction time to various stimuli (Lemmink \& Visscher, 2005). Other authors noted that physical exercise can affect the length of the reaction time (Collardeau, Brisswalter, \& Audiffren, 2001). Levitt and Gutin (1971) noted that their participants reacted faster when their heart rate reached a value of 115 beats per minute after prolonged exercise. Kashihara and Nakahara (2005) indicated that vigorous exercise shortened reaction time, but only in the first 8 minutes of the activity.

In our study, the reaction time to visual stimuli among the schoolchildren who had been training for longer was shorter, but the strength of the association was not statistically significant. However, Kumar (2013) noticed a significant negative correlation between the length of the sport engagement and the reaction time to visual stimuli. Their participants had been training longer than our own, which probably affected the results.

When analyzing our results, we noticed that the reaction time to visual stimuli statistically significantly reduced with age. Our results are in correlation with literature findings which indicate that reaction time becomes shorter from early childhood to the late twenties, and then gradually increases with age (Welford, 1977; Jevas \& Yan, 2001; Rose, Feldman, Jankowski, \& Caro, 2002).

When we utilized tests to estimate the usable and gestural lateralization of the extremities, vision and hearing, we found the dominant lateralization of the right hand in 93\% of the participants, which was accompanied by the dominant lateralization of the right leg, vision and hearing. Only $7 \%$ of the participants exhibited the dominant lateralization of the left hand, followed by the usable lateralization of the left leg, vision and hearing. There was no statistically significant difference in the speed of the reaction between the usable lateralization of the participants. These findings are in accordance with the work of 
Korovljev et al. (2011) where pre-school children were tested (202 children, 95 of whom were left-handed) and where it was determined that there were no statistically significant differences in carrying out motor assignments between the right-handed and the lefthanded participants. In their studies, Dane and Erzurumluoglu (2003) did not detect a difference in the speed of the reaction between the left-handed and the right-handed handball players. Iteya and Gabbard (1996) claimed that, in their study, the right-handed children were better coordinated than the left-handed children.

The schoolchildren from the "Beovuk 72" sports club, who had been training basketball for several years, had a statistically significant shorter reaction time to visual stimuli than schoolchildren from the "Knez Lezar" Elementary School, who did not engage in sports. Davranche et al. (2006) also noted that active exercise reduces reaction time. Meden et al. (2011), tested the reaction time to visual stimuli among students, both athletes and non-athletes, where athletes had a significantly shorter reaction time to visual stimuli compared to nonathletes. Medical students who engaged in sports had a faster reaction time to audio and visual stimuli than medical students with a sedentary lifestyle (Jain et al., 2015).

\section{CONCLUSION}

The reaction time to visual stimuli has significantly helped us to evaluate the speed and explosive abilities of young basketball players. With the training of certain movements (their constant repetition), we managed to improve the reaction time in these movements and positively influence the speed and explosive abilities of young basketball players. Their sensitive age probably contributed to these findings.

\section{REFERENCES}

Adam, J. (1999). Gender differences in choice reaction time: Evidence for differential strategies. Ergonomics, 42(2), 327-335.

Bellis, C.J. (1933). Reaction time and chronological age. Proceedings of the Society for Experimental Biology and Medicine, 30(6), 801-803.

Bojanin, S., \& Elim, M.G. (1985). Neuropsihologija razvojnog doba i opšti re-edukativni metod (Neuropsychology of developmental age and general re-eductive method). Belgrade: Zavod za udžbenike $\mathrm{i}$ nastavna sredstva. In Serbian

Collardeau, M., Brisswalter, J., \& Audiffren, M. (2001). Effects of a prolonged run on simple reaction time of well-trained runners. Perceptual and Motor Skills, 93 (3), 679-689.

Dane, S., \& Erzurumluoglu, A. (2003). Sex and handedness differences in eye-hand visual reaction times in handball players. International Journal of Neuroscience, 113 (7), 923-929.

Davranche, K., Burle, B., Audiffren, M., \& Hasbroucq, T. (2006). Physical exercise facilitates motor processes in simple reaction time performance: An electromyographic analysis. Neuroscience Letters, 396(1), 54-56.

Engel, B.T., Thorne, P.R., \& Quilter, R.E. (1972). On the relationship among sex, age, response mode, cardiac cycle phase, breathing cycle phase, and simple reaction time. Journal of Gerontology, 27, 456-460.

Gavkare, A., Wanaware, N., \& Svedi, A. (2013). Auditory reaction time, visual reaction time and whole body reaction time in athletes. Indian Medical Gazette, 6, 214-219.

Iteya, M., \& Gabbard, C. (1996).Laterality patterns and visual-motor coordination of children. Perceptual and Motor Skills, 83(1) 31-34.

Jain, A., Bansal, R., Kumar, A., \& Singh, K.D. (2015). A comparative study of visual and auditory reaction times on the basis of gender and physical activity levels of medical first year students. International Journal of Applied and Basic Medical Research, 5(2), 124-127. 
Jakovljević, S., Karalejić, M., Pajić, Z. Gardašević, B., \& Mandić, R. (2011). The influence of anthropometric characteristics on the agility abilities of 14 year-old elite male basketball players. Facta Universitatis Series Physical Education and Sport, 9 (2), 141-149.

Jakovljević, A., Nestorović, V., Dejanović, M., Bukumirić, Z., Jakovljević, A., \& Đoković, N. (2008). Evaluation of the cognitive and affective status in hemodialysis patients with chronic renal failure. Medicinski pregled, 71 (7-8), 222-226.

Jevas, S., \& Yan, J.H. (2001). The effect of aging on cognitive function: a preliminary quantitative review. Research Quarterly for Exercise and Sport, 72, A-49.

Kashihara, K., \& Nakahara, Y. (2005). Short-term effect of physical exercise at lactate threshold on choice reaction time. Perceptual and Motor Skills, 100 (2), 275-281.

Korovljev, D., Mikalački,M., \& Čokorilo, N. (2011). Razlike u motoričkim sposobnostima za energetsku regulaciju kod predškolske dece sa različitom lateralizovanošću gornjih ekstremiteta (Differences in motorical abilities for the energetical regulation for pre-school children with various lateralization of the upper extremities). Journal of the Anthropologycal Society of Serbia, 46, 421-427. In Serbian

Kumar, A. (2013). Visual response time and visuospatial intelligence scores of athletes and non-athletes. Journal of Exercise Science and Physiotherapy, 9(2), 125-128.

Lemmink, K. \& Visscher, C. (2005). Effect of intermittent exercise on multiple-choice reaction times of soccer players. Perceptual and Motor Skills, 100 (1), 85-95.

Levitt, S., \& Gutin, B. (1971). Multiple choice reaction time and movement time during physical exertion. Research Quarterly, 42, 405-410.

Luchies, C.W., Schiffman, J., Richards, L.G., Thompson, M.R., Bazuin, D., \& DeYoung, A.J. (2002). Effects of age, step direction, and reaction condition on the ability to step quickly. The Journals of Gerontology, Series A, 57(4), 246.

Meden, A., Wright, M.S., \& Hamilton, B. (2011) Waynesburg University, Department of Biology, Waynesburg. The observance of the visual reaction time of non-athletes compared to athletes. Retrived February 25, 2018 from the World Wide Web: https://www.waynesburg.edu/docman/70.

Mišolić, M., Ivetić, V., Nestorović, V., Milanović, Z., Radović, D., Biševac, B., \& Erić, M. (2008). Functional condition influence on students' reaction time. Praxis Medica, 36 (3-4), 53-56.

Quintana, M.S., Román, I.R., Calvo, A.L., \& Molinuevo, J.S. (2007). Perceptual visual skills in young highly skilled basketball players. Perceptual and Motor Skills, 104(2), 547-561.

Rose, S.A., Feldman, J.F., Jankowski, J.J., \& Caro, D.M. (2002). A longitudinal study of visual expectation and reaction time in the first year of life. Child Development, 73(1), 47-61.

Trunić, N., \& Mladenović, M. (2015). Metodski pristup razvoju brzinsko-eksplozivnih sposobnosti u košarci (Methodological approach to the development of speed-explosive abilities in basketball). Sport-Nauka $i$ Praksa, 5(1-2), 41-53. In Serbian

Welford, A.T. (1977). Motor performance. In J.E. Birren, \& K.W. Schaie (Eds.), Handbook of the Psychology of Aging. (pp. 450-496), Van Nostrand Reinhold, New York.

\section{PROCENA BRZINE VREMENA REAKCIJE NA VIZUELNE DRAŽI KOD DECE ŠKOLSKOG UZRASTA}

Brza reakcija na vizuelne stimuluse značajna je za uspeh svakog sportiste. Kratko vreme reakcije omogućava brz odgovor u ključnim situacijama. Istraživali smo kako uzrast, bavljenje sportom, umerena fizička aktivnost i lateralizovanost utiču na prosto reakciono vreme na vizuelne draži kod dece školskog uzrasta od 9-13 godina. Sa uzrastom reakciono vreme na vizuelne draži statistički se značajno skraćivalo. Košarkaši sportskog kluba koji su nekoliko godina trenirali i igrali košarku imali su statistički značajno kraće reakciono vreme na vizuelne draži u odnosu na školsku decu istog uzrasta iz seoske sredine koja se nisu bavili sportom. Umerena fizička aktivnost i lateralizovanost nisu značajno uticali na dužinu reakcionog vremena. Vreme rekacije na vizuelne draži poslužilo nam j za procenu brzinsko-eksplozivnih sposobnosti mladih košarkaša.Treningom određenih pokreta uspeli smo da im poboljšamo reakciono vreme i tako utičemo na kvalitet njihove igre.Trening ovih sposobnosti u klubovima i školama uticao bi na poboljšanje košarkaške igre i sprečavanje povreda.

Ključne reči: prosto reakciono vreme, vizuelne draži, fizička aktivnost, lateralizovanost. 